\title{
Thiopentone does not block ischemic precondi- tioning in the isolated rat heart
}

\section{[Le thiopental n'entrave pas le préconditionnement ischémique dans le caur} de rat isolé]

J. Müllenheim MD,${ }^{*}$ A. Molojavyi MD, $†$ B. Preckel MD DEAA, ${ }^{*}$ V. Thämer MD, $†$ W. Schlack MD DEAA

Purpose: Ischemic preconditioning protects the heart against subsequent prolonged ischemia by opening of adenosine triphosphatesensitive potassium $\left(K_{\text {ATP }}\right)$ channels. Thiopentone blocks $K_{\text {ATP }}$ channels in isolated cells. Therefore, we investigated the effects of thiopentone on ischemic preconditioning.

Methods: Isolated rat hearts $(n=56)$ were subjected to 30 min of global no-flow ischemia, followed by $60 \mathrm{~min}$ of reperfusion. Thirteen hearts underwent the protocol without intervention (control, CON) and in II hearts (preconditioning, PC), ischemic preconditioning was elicited by two five-minute periods of ischemia. In three additional groups, hearts received I (Thio I, $n=1$ I), 10 (Thio 10, $n=11$ ) or $100 \mu \mathrm{g} \cdot \mathrm{mL}^{-1}$ (Thio 100, $n=10$ ) thiopentone for five minutes before preconditioning. Left ventricular (LV) developed pressure and creatine kinase $(\mathrm{CK})$ release were measured as variables of myocardial performance and cellular injury, respectively. Results: Recovery of LV developed pressure was improved by ischemic preconditioning (after 60 min of reperfusion, mean \pm SD: PC, $40 \pm 19 \%$ of baseline) compared with the control group ( $5 \pm$ $6 \%, P<0.01)$ and this improvement of myocardial function was not altered by administration of thiopentone (Thio I, $37 \pm 15 \%$; Thio 10, $36 \pm 16 \%$; Thio 100, $38 \pm 16 \%, P=0.87-0.99$ vs PC). Total CK release over $60 \mathrm{~min}$ of reperfusion was reduced by preconditioning (PC, $202 \pm 82 \mathrm{U} \cdot \mathrm{g}^{-1}$ dry weight) compared with controls (CON, $\left.383 \pm 147 \mathrm{U} \cdot g^{-1}, P<0.01\right)$ and this reduction was not affected by thiopentone (Thio I, $213 \pm 69 \mathrm{U} \cdot \mathrm{g}^{-1}$; Thio I0, 211 $\pm 98 \mathrm{U} \cdot g^{-1}$; Thio $100,258 \pm 128 \mathrm{U} \cdot g^{-1}, P=0.62-1.0 \mathrm{vs}$ PC).

Conclusion: These results indicate that thiopentone does not block the cardioprotective effects of ischemic preconditioning in an isolated rat heart preparation.
Objectif : Le préconditionnement ischémique protège le cœur contre l'ischémie ultérieure prolongée en ouvrant les canaux potassiques sensibles à l'adénosine triphosphate (KATP). Or, le thiopental bloque les canaux KATP dans des cellules isolées. Nous avons donc recherché les effets du thiopental sur le préconditionnement ischémique.

Méthode : Des cœurs de rats isolés $(n=56)$ ont été soumis à 30 min d'ischémie globale à débit nul, puis de 60 min, à une reperfusion. Treize cœurs ont subi le protocole sans intervention (témoin. TEM) et dans onze cours (groupe de préconditionnement, $P C$ ) le préconditionnement ischémique a été amorcé par deux périodes de cinq minutes d'ischémie. Dans trois groupes additionnels, les cœurs ont reçu I (Thio I, $n=11$ ), 10 (Thio 10, $n=11$ ) ou $100 \mu \mathrm{g} \cdot \mathrm{mL}^{-1}$ (Thio 100, $n=10)$ de thiopental pendant cinq minutes avant le préconditionnement. La pression du ventricule gauche (VG) développée et la libération de créatine kinase (CK) ont été mesurées en qualité de variables de la performance myocardique et de la lésion cellulaire, respectivement.

Résultats : La récupération de la pression du VG développée a été améliorée par le préconditionnement ischémique (après 60 min de reperfusion, la moyenne \pm l'écart type : $P C, 40 \pm 19 \%$ de la mesure de base) comparée au groupe témoin $(5 \pm 6 \%, P<0,01)$. Cette amélioration de la fonction myocardique n'a pas été modifiée par l'administration de thiopental (Thio I, $37 \pm 15 \%$; Thio 10, $36 \pm 16 \%$; Thio $100,38 \pm 16 \%, P=0,87-0,99$ vs $P C$ ). La libération totale de $C K$ après 60 min de reperfusion a été réduite par le préconditionnement ( $P C, 202 \pm 82 \mathrm{U} \cdot \mathrm{g}^{-1}$ de poids anhydre) comparé au témoin (TEM, $383 \pm 147 \mathrm{U} \cdot g^{-1}, P<0,01$ ) et cette réduction n'a pas été affectée par le thiopental (Thio 1, $213 \pm 69 \mathrm{U} \cdot \mathrm{g}^{-1}$; Thio 10, $211 \pm$ $98 \mathrm{U} \cdot g^{-1}$; Thio $100,258 \pm 128 \mathrm{U} \cdot \mathrm{g}^{-1}, P=0,62-1,0 \mathrm{vs} P()$.

Conclusion : Ces résultats indiquent que le thiopental ne bloque pas les effets cardioprotecteurs du préconditionnement ischémique dans une préparation de cour de rat isolé.

From the Departments of Anaesthesiology, ${ }^{*}$ and Physiology, $†$ Institut I, Heinrich-Heine-Universität, Düsseldorf, Germany.

Address correspondence to: Dr. W. Schlack, Klinik für Anaesthesiologie Heinrich-Heine-Universität Postfach, 101007, 40001 Düsseldorf, Germany. Phone: +49-211-811-8669; Fax: +49-211-811-6253; E-mail: wolfgang@herzkreis.uni-duesseldorf.de

Accepted for publication March 27, 2001

Revision accepted May 9, 2001. 
$\mathrm{R}$ EPEATED short periods of ischemia render the heart more resistant to a subsequent prolonged ischemia, a phenomenon known as ischemic preconditioning. The pronounced cardioprotective effects of ischemic preconditioning have been demonstrated by an improved post-ischemic functional recovery and by a reduction of myocardial infarct size and of the incidence and severity of arrhythmias. ${ }^{1}$ Preconditioning may be an important cardioprotective mechanism in patients with coronary artery disease. ${ }^{2}$ One key mechanism involved is the activation of adenosine triphosphate(ATP) sensitive potassium $\left(\mathrm{K}_{\mathrm{ATP}}\right)$ channels. $^{3}$ Anesthetics can block (e.g., ketamine ${ }^{4}$ ) or open (e.g., isoflurane $\left.{ }^{5}\right) \mathrm{K}_{\mathrm{ATP}}$ channels, and thereby, can block ${ }^{6,7}$ or mimic ischemic preconditioning. ${ }^{8}$ Thiopentone was reported to block $\mathrm{K}_{\text {ATP }}$ channels in isolated cells at concentrations that may be clinically relevant. ${ }^{9,10}$ Therefore, the present study tested the hypothesis that thiopentone may block the cardioprotective effects of ischemic preconditioning. To address this question, thiopentone was administered to isolated rat hearts just before the preconditioning ischemias. Left ventricular (LV) developed pressure and creatine kinase $(\mathrm{CK})$ release were determined during reperfusion after a 30 -min period of no-flow ischemia as variables of myocardial function and cellular injury, respectively.

\section{Methods}

The experiments were performed in accordance with the regulations of the German Animal Protection Law and local institutional regulations. The exact procedure was described in detail previously. ${ }^{11}$ In brief, hearts from halothane anesthetized male Wistar rats (300-350 g bodyweight) were excised and mounted on a Langendorff perfusion system. Retrograde perfusion via the aorta was initiated in a constant pressure mode $(80 \mathrm{mmHg})$ with an oxygenated modified Krebs-Henseleit buffer. The heart rate of the isovolumetric beating hearts was maintained at 375 beats. $\mathrm{min}^{-1}$ by atrial pacing. Thiopentone dissolved in Krebs-Henseleit buffer was infused into the perfusion system near the aortic cannula at $1 / 100$ of total coronary flow using a calibrated syringe pump (Model 5003, Precidor Infors, Basel, Switzerland) in order to achieve final concentrations of 1,10 or $100 \mu \mathrm{g} \cdot \mathrm{mL}^{-1}$, respectively. LV developed pressure, the peak positive $\left(\mathrm{dP} / \mathrm{dt}_{\max }\right)$ and negative $\left(\mathrm{dP} / \mathrm{dt}_{\min }\right)$ velocity of the change of LV pressure and total CK release during the 60-min reperfusion period were measured as variables of myocardial performance and cellular injury, respectively. After each experiment, the wet and dry weight of the heart was determined. Mean wet weight was
$1.0 \mathrm{~g}$ (range $0.8-1.4 \mathrm{~g}$ ), and mean dry weight was $0.21 \mathrm{~g}$ (range $0.15-0.30 \mathrm{~g}$ ), similar in all groups. Myocardial oxygen consumption and $\mathrm{CK}$ release are expressed per gram of dry tissue.

The experimental program consisted of four phases (Figure 1). At the end of a 20-min stabilisation period baseline values were recorded. An intervention period (30 $\mathrm{min})$, global no-flow ischemia (30 $\mathrm{min}$ ) and reperfusion period $(60 \mathrm{~min})$ followed. Control hearts $(\mathrm{CON}$, $n=13$ ) received no treatment during the intervention phase. In all other groups, ischemic preconditioning (PC, $n=11$ ) was induced by two five-minute periods of no-flow ischemia, each followed by ten and five minutes of reperfusion, respectively. The hearts of the three thiopentone groups received either 1 (Thio $1, n=11$ ), 10 (Thio $10, n=11$ ) or $100 \mathrm{\mu g} \cdot \mathrm{mL}^{-1}$ thiopentone (Thio $100, n=10$ ) continuously for five minutes prior to the two five minute preconditioning ischemias.

Data are presented as mean and standard deviation (SD). Statistical analysis was performed by two-way analysis of variance (ANOVA) for time and treatment (experimental group) effects. If an overall significance between groups was found, comparison was done for each time point using one-way ANOVA followed by the Dunnett's post-hoc test with PC as the reference group. If an overall significance within a group (time effect) was found, one-way ANOVA followed by the Dunnett's post-hoc test with the baseline value as the reference time point was used for the assessment of time effects in the respective group. Changes within and between groups were considered statistically significant when the $P$ value was less than 0.05 . The study was designed to detect a $15 \%$ difference of the final recovery in LV developed pressure with a power of 0.9 and a group size of 10 .

\section{Results}

A total of 56 hearts were included in the statistical analysis. Baseline values were similar in all groups [LV developed pressure $105 \pm 20 \mathrm{mmHg} ; \mathrm{LV}$ end-diastolic pressure (LVEDP) $10 \pm 5 \mathrm{mmHg}$ ] (Table). In the preconditioning group, the two five-minute periods of ischemia had nearly no influence on hemodynamic variables except for LV developed pressure which decreased from $99 \pm 9 \mathrm{mmHg}$ to $75 \pm 14 \mathrm{mmHg}$ after the short reperfusion periods prior to the $30 \mathrm{~min}$ ischemia ( $P$ $<0.01$ vs baseline). During ischemia, LVEDP of controls increased to a peak value of $51 \pm 10 \mathrm{mmHg}(P<0.01$ vs baseline) after $25 \mathrm{~min}$, indicating myocardial contracture (Table). During early reperfusion, there was a further increase of LVEDP reaching a maximum of $125 \pm 14$ $\mathrm{mmHg}(P<0.01$ vs baseline $)$ at five minutes reperfusion (reperfusion contracture). At the end of the experiment, 
TABLE Hemodynamic variables

\begin{tabular}{|c|c|c|c|c|c|c|}
\hline & \multirow[t]{2}{*}{ Baseline } & \multicolumn{2}{|c|}{ Ischemia } & \multicolumn{3}{|c|}{ Reperfusion } \\
\hline & & $5 \mathrm{~min}$ & $25 \mathrm{~min}$ & $5 \mathrm{~min}$ & $30 \mathrm{~min}$ & $60 \mathrm{~min}$ \\
\hline \multicolumn{7}{|l|}{ LVEDP (mmHg) } \\
\hline Control & $10.9 \pm 1.9$ & $21.2 \pm 9.8$ & $50.8 \pm 10.2 * \dagger$ & $124.6 \pm 14.2^{*} \dagger$ & $96.9 \pm 12.6^{*} \dagger$ & $89.6 \pm 13.5^{*} \dagger$ \\
\hline PC & $10.3 \pm 5.9$ & $12.4 \pm 7.3$ & $23.8 \pm 8.1$ & $84.8 \pm 18.2^{*}$ & $45.6 \pm 20.6^{*}$ & $35.9 \pm 17.2^{*}$ \\
\hline PC \& Thio $1 \mu \mathrm{g} \cdot \mathrm{mL}^{-1}$ & $10.2 \pm 7.2$ & $27.4 \pm 15.9 \dagger$ & $36.2 \pm 16.7^{\star}$ & $88.0 \pm 24.3^{*}$ & $56.8 \pm 26.5^{*}$ & $51.2 \pm 26.1^{*}$ \\
\hline PC \& Thio $10 \mu \mathrm{g} \cdot \mathrm{mL}^{-1}$ & $10.2 \pm 4.6$ & $24.0 \pm 15.0$ & $34.3 \pm 18.4^{*}$ & $98.1 \pm 24.5^{*}$ & $66.8 \pm 16.7^{*}$ & $49.7 \pm 17.2^{*}$ \\
\hline PC \& Thio $100 \mu \mathrm{g} \cdot \mathrm{mL}^{-1}$ & $8.8 \pm 3.9$ & $21.4 \pm 15.2$ & $36.7 \pm 15.4^{*}$ & $90.7 \pm 18.5^{*}$ & $47.3 \pm 19.0^{*}$ & $43.2 \pm 20.1^{*}$ \\
\hline \multicolumn{7}{|l|}{$d P / d t_{\max }\left(m m H g s e c^{-1}\right)$} \\
\hline Control & $3276 \pm 732$ & $627 \pm 403^{*}$ & $631 \pm 419^{*}$ & $658 \pm 407^{*}$ & $761 \pm 455^{*} \dagger$ & $777 \pm 514^{*} \dagger$ \\
\hline PC & $3312 \pm 411$ & $487 \pm 168^{*}$ & $506 \pm 173^{*}$ & $680 \pm 439^{*}$ & $1645 \pm 892^{*}$ & $1656 \pm 719^{*}$ \\
\hline PC \& Thio $1 \mu \mathrm{g} \cdot \mathrm{mL}^{-1}$ & $3398 \pm 539$ & $530 \pm 150^{*}$ & $529 \pm 150^{*}$ & $693 \pm 215^{*}$ & $1430 \pm 505^{*}$ & $1593 \pm 475^{*}$ \\
\hline PC \& Thio $10 \mu \mathrm{g} \cdot \mathrm{mL}^{-1}$ & $3579 \pm 610$ & $619 \pm 198^{*}$ & $615 \pm 194^{*}$ & $643 \pm 157^{*}$ & $1351 \pm 507^{*}$ & $1485 \pm 580^{*}$ \\
\hline PC \& Thio $100 \mu \mathrm{g} \cdot \mathrm{mL}^{-1}$ & $2967 \pm 524$ & $673 \pm 492^{\star}$ & $496 \pm 256^{*}$ & $786 \pm 398^{*}$ & $1389 \pm 518^{*}$ & $1565 \pm 462^{*}$ \\
\hline \multicolumn{7}{|l|}{$d P / d t_{\min }\left(m m H g s e c^{-1}\right)$} \\
\hline Control & $-2582 \pm 606$ & $-624 \pm 394^{*}$ & $-594 \pm 343^{*}$ & $-593 \pm 388^{*}$ & $-684 \pm 357^{*} \dagger$ & $-720 \pm 394^{*} \dagger$ \\
\hline PC & $-2530 \pm 400$ & $-497 \pm 157^{*}$ & $-466 \pm 169^{*}$ & $-650 \pm 354^{*}$ & $-1330 \pm 771^{*}$ & $-1308 \pm 533^{*}$ \\
\hline PC \& Thio $1 \mu \mathrm{g} \cdot \mathrm{mL}^{-1}$ & $-2603 \pm 542$ & $-506 \pm 126^{*}$ & $-548 \pm 124^{*}$ & $-649 \pm 161^{*}$ & $-1170 \pm 419^{*}$ & $-1197 \pm 377^{*}$ \\
\hline PC \& Thio $10 \mu \mathrm{g} \cdot \mathrm{mL}^{-1}$ & $-2867 \pm 607$ & $-623 \pm 217^{*}$ & $-607 \pm 199^{*}$ & $-609 \pm 132^{*}$ & $-1201 \pm 428^{*}$ & $-1204 \pm 395^{*}$ \\
\hline PC \& Thio $100 \mu \mathrm{g} \cdot \mathrm{mL}^{-1}$ & $-2370 \pm 478$ & $-631 \pm 477^{*}$ & $-511 \pm 253^{*}$ & $-722 \pm 385^{*}$ & $-1215 \pm 447^{*}$ & $-1281 \pm 391^{*}$ \\
\hline \multicolumn{7}{|l|}{$\mathrm{VO}_{2}\left(m L \cdot g^{-1} \mathrm{~min}^{-1}\right)$} \\
\hline Control & $1.26 \pm 0.39$ & & & $0.56 \pm 0.25^{*}$ & $0.52 \pm 0.21^{*}$ & $0.52 \pm 0.18^{*}$ \\
\hline PC & $1.21 \pm 0.37$ & & & $0.84 \pm 0.29$ & $0.72 \pm 0.24^{*}$ & $0.71 \pm 0.33^{*}$ \\
\hline PC \& Thio $1 \mu \mathrm{g} \cdot \mathrm{mL}^{-1}$ & $1.08 \pm 0.31$ & & & $0.68 \pm 0.20^{*}$ & $0.61 \pm 0.16^{*}$ & $0.58 \pm 0.17^{*}$ \\
\hline PC \& Thio $10 \mu \mathrm{g} \cdot \mathrm{mL}^{-1}$ & $1.42 \pm 0.62$ & & & $0.93 \pm 0.54$ & $0.86 \pm 0.46^{*}$ & $0.77 \pm 0.44^{*}$ \\
\hline PC \& Thio $100 \mu \mathrm{g} \cdot \mathrm{mL}^{-1}$ & $1.08 \pm 0.5$ & & & $0.72 \pm 0.34$ & $0.71 \pm 0.36$ & $0.67 \pm 0.38$ \\
\hline
\end{tabular}

Data are mean $\pm \mathrm{SD}$. PC=preconditioning; Thio=thiopentone; $\mathrm{LVEDP}=$ left ventricular end-diastolic pressure; $\mathrm{dP} / \mathrm{dt}_{\max }$ and $\mathrm{dP} / \mathrm{dt}_{\min }=$ peak positive and negative velocity of change of left ventricular pressure; $\mathrm{VO}_{2}=$ myocardial oxygen consumption per $\mathrm{g} d \mathrm{dry}$ weight; ${ }^{*} P<0.05$ vs baseline; $\uparrow P<0.05$ vs $\mathrm{PC}$.

LVEDP was still elevated $(90 \pm 14 \mathrm{mmHg}, P<0.01$ vs baseline). Ischemic preconditioning reduced the degree of myocardial contracture in the ischemic period (LVEDP after $25 \mathrm{~min}$ ischemia: $24 \pm 8 \mathrm{mmHg}, P<0.01$ $v s$ control) as well as in the reperfusion period (LVEDP after $60 \mathrm{~min}$ of reperfusion: $36 \pm 17 \mathrm{mmHg}, P<0.01$ vs control). Post-ischemic function of control hearts was markedly depressed and LV developed pressure recovered to only $5 \pm 6 \%$ of baseline values $(P<0.01$ vs $\mathrm{PC})$ after $60 \mathrm{~min}$ of reperfusion (Figure 2). The preconditioning protocol resulted in a better preservation of myocardial performance after $60 \mathrm{~min}$ of reperfusion in comparison with control hearts. LV developed pressure finally reached $40 \pm 19 \%$ of baseline values (Figure $2, P$ $<0.01$ vs control). Diastolic function was also improved by preconditioning. $\mathrm{DP} / \mathrm{dt}_{\min }$ was higher in preconditioned hearts in comparison with controls at the end of the reperfusion period. Ischemic preconditioning reduced cumulative CK release after $60 \mathrm{~min}$ of reperfusion from $383 \pm 147 \mathrm{U} \cdot \mathrm{g}^{-1}$ dry weight (Figure 3 ) in control hearts to $202 \pm 82 \mathrm{U} \cdot \mathrm{g}^{-1}(P<0.01)$. Despite reduced cellular injury, myocardial oxygen consumption was not significantly different in comparison with control hearts. The two five-minute periods of continuous thiopentone administration did not significantly change hemodynamics, regardless of the concentration used. Furthermore, thiopentone administration prior to ischemic preconditioning had no effect on myocardial contracture, functional recovery, myocardial oxygen consumption and cellular damage during the course of the experiment when compared with the PC group (Table, Figures 2 and 3). LV developed pressure after $60 \mathrm{~min}$ of reperfusion (Figure 2; Thio 1, $36 \pm 11 \mathrm{mmHg}$; Thio 10, $42 \pm$ $22 \mathrm{mmHg}$; Thio $100,35 \pm 15 \mathrm{mmHg} ; P=0.97-1.0$ vs PC) and cumulative CK release (Thio $1,213 \pm 69 \mathrm{U} \cdot \mathrm{g}^{-1}$; Thio 10, $211 \pm 98 \mathrm{U} \cdot \mathrm{g}^{-1}$; Thio $100,258 \pm 128 \mathrm{U} \cdot \mathrm{g}^{-1}$; $P=0.62-1.0$ vs PC) (Figure 3) were not different in comparison with preconditioned hearts.

\section{Discussion}

The main finding of the present study is that thiopentone in a concentration up to $100 \mu \mathrm{g} \cdot \mathrm{mL}^{-1}$ does not abolish the cardioprotective effects of ischemic preconditioning as indicated by a preserved improvement of functional recovery and reduction of cellular injury induced by ischemic preconditioning.

Brief periods of myocardial ischemia followed by reperfusion provide strong endogenous myocyte pro- 


\begin{tabular}{|c|c|c|c|c|}
\hline \multicolumn{5}{|c|}{ control $(n=13)$} \\
\hline \multicolumn{4}{|c|}{$20 \mathrm{~min}$} & \multirow{2}{*}{$\frac{60 \mathrm{~min}}{\text { reperfusion }}$} \\
\hline stab. & & & ischemia & \\
\hline \multicolumn{5}{|c|}{ preconditioning ( $n=11)$} \\
\hline $20 \mathrm{~min}$ & $5 \min$ & $5 \min$ & $30 \mathrm{~min}$ & $60 \mathrm{~min}$ \\
\hline stab. & $\mathrm{P}$ & $\mathrm{P} \mid$ & ischemia & reperfusion \\
\hline
\end{tabular}

\section{Thiopental:}

(Thio 1, $\mathrm{n}=11$ ); (Thio 10, $\mathrm{n}=11$ ); (Thio 100, $\mathrm{n}=10$ )

\begin{tabular}{|c|c|c|c|c|}
\hline $20 \mathrm{~min}$ & $5 \mathrm{~min}$ & $5 \mathrm{~min}$ & 30min & $60 \mathrm{~min}$ \\
\hline stab. & $\mathrm{T}|\mathrm{P}|$ & $\mathrm{T} \mid \mathrm{P}$ & ischemia & reperfusion \\
\hline
\end{tabular}

FIGURE 1 The experimental program consisted of four phases: stabilisation (stab., $20 \mathrm{~min}$ ), intervention (30 $\mathrm{min}$ ), global no-flow ischemia $(30 \mathrm{~min})$ and reperfusion $(60 \mathrm{~min})$. Ischemic precondiischemia $(30 \mathrm{~min})$ and reperfusion $(60 \mathrm{~min})$. Ischemic precondi-
tioning $(\mathrm{P})$ was elicited by two five-minute periods of ischemia foltioning $(\mathrm{P})$ was elicited by two five-minute periods of ischemis
lowed by ten and five minutes of reperfusion, respectively. lowed by ten and five minutes of reperfusion, respectively.
Thiopentone $(\mathrm{T})$ was administered in three different concentrations [thiopentone group $1 \mu \mathrm{g} \cdot \mathrm{mL}^{-1}$ (Thio 1 ), thiopentone group $10 \mu \mathrm{g} \cdot \mathrm{mL}^{-1}$ (Thio 10 ), thiopentone group $100 \mu \mathrm{g} \mathrm{mL}^{-1}$ (Thio 100)] for five minutes prior to the two preconditioning ischemias.

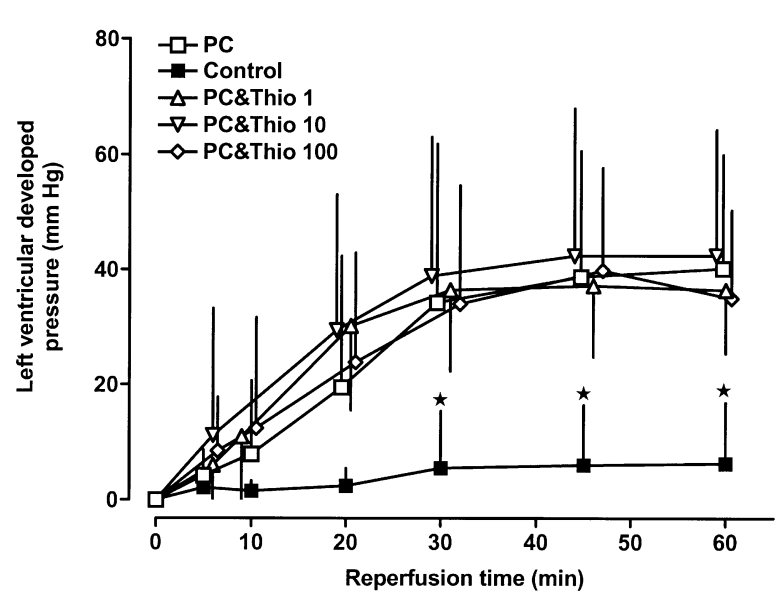

FIGURE 2 Effects of ischemic preconditioning and thiopentone pre-treatment before ischemic preconditioning on the recovery of left ventricular (LV) developed pressure during the reperfusion phase. LV developed pressure is plotted as a function of time. Data are expressed as mean $\pm \mathrm{SD}, n=11$ for preconditioning group (PC), $n=13$ for control group (CON), $n=11$ for thiopentone group $1 \mu \mathrm{g} \cdot \mathrm{mL}^{-1}$ (Thio 1 ), $n=11$ for thiopentone group 10 $\mu \mathrm{g} \cdot \mathrm{mL}^{-1}$ (Thio 10 ), $n=10$ for thiopentone group $100 \mu \mathrm{g} \cdot \mathrm{mL}^{-1}$ $\mu \mathrm{g} \cdot \mathrm{mL}^{-1}$ (Thio 10$), n=10$ for
(Thio 100) ${ }^{*} P<0.05$ ps $\mathrm{PC}$.

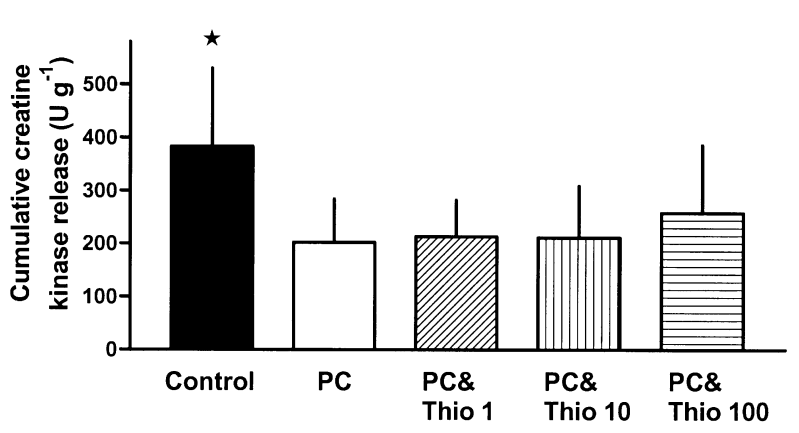

FIGURE 3 Effects of ischemic preconditioning and thiopentone pre-treatment before ischemic preconditioning on cumulative creatine kinase $(\mathrm{CK})$ release during the 60 -min period of reperfusion. Data are expressed as mean $\pm \mathrm{SD}, n=11$ for preconditioning group (PC), $n=13$ for control group, $n=11$ for thiopentone group 1 $\mu \mathrm{g} \cdot \mathrm{mL}^{-1}$ (Thio 1 ), $n=11$ for thiopentone group $10 \mu \mathrm{g} \cdot \mathrm{mL}^{-1}$ (Thio 10), $n=10$ for thiopentone group $100 \mu \mathrm{g} \cdot \mathrm{mL}^{-1}$ (Thio 100$) .{ }^{*} P$ $<0.05$ vs PC.

tection from a subsequent ischemic insult. This concept, known as "ischemic preconditioning", has been shown to occur in all animals studied, including humans. ${ }^{12}$ Although the signal transduction pathway of ischemic preconditioning is not fully understood, the overwhelming majority of evidence suggests that opening of $\mathrm{K}_{\mathrm{ATP}}$ channels is an important component of this phenomenon. ${ }^{13,14}$ Kozlowski and Ashford investigated the effects of thiopentone on $\mathrm{K}_{\mathrm{ATP}}$ channels in insulin secreting cells. ${ }^{9}$ They found that the $\mathrm{K}_{\text {ATP }}$ channel activity is inhibited by thiopentone with an $\mathrm{IC}_{50}$ value of $62 \mu \mathrm{M}$. Based on this finding, we hypothesized that thiopentone might block ischemic preconditioning like ketamine ${ }^{6,7}$ which also possesses a $\mathrm{K}_{\text {ATP }}$ channel blocking activity. ${ }^{4}$ Surprisingly, we observed a preservation of the cardioprotective effects of ischemic preconditioning despite the administration of relatively high concentrations of thiopentone prior to the preconditioning ischemias. To explain this finding one might first consider the presence of different sulfonylurea receptors (SUR) to form the active $\mathrm{K}_{\mathrm{ATP}}$ channel (SUR 2a in the heart, SUR 1 in pancreatic $B$-cells) resulting in differential pharmacological properties of blocking agents on $\mathrm{K}_{\mathrm{ATP}}$ channels in different tissues. ${ }^{15}$ Thus, it is conceivable that thiopentone does not block cardiac $\mathrm{K}_{\mathrm{ATP}}$ channels. However, Tsutsumi et al. reported that thiamylal inhibits $\mathrm{K}_{\mathrm{ATP}}$ channel activities in rat ventricular myocytes at clinically relevant concentrations. ${ }^{10}$ In contrast to our study, Tsutsumi et al. and Kozlowski and Ashford investigated the effects of thiobarbiturates on $\mathrm{K}_{\text {ATP }}$ 
channels in isolated cells by using patch-clamp recording techniques, thereby investigating sarcolemmal $\mathrm{K}^{+}$ currents. Evidence from Garlid's and Marban's laboratory implies that the recently identified mitochondrial rather than the sarcolemmal $\mathrm{K}_{\mathrm{ATP}}$ channel is primarily involved in the cardioprotection induced by preconditioning. ${ }^{3}$ Our findings of a preservation of the cardioprotective effects of ischemic preconditioning after the administration of thiopentone may therefore indicate different activities of thiopentone on sarcolemmal and mitochondrial SUR. This hypothesis could also explain why several studies were able to investigate ischemic preconditioning in vivo during barbiturate anesthesia, ${ }^{16}$ but has yet to be proven with direct techniques investigating $\mathrm{K}^{+}$currents at mitochondrial membranes of myocytes.

Three different concentrations of thiopentone were used in the present study. While the highest concentration of $100 \mu \mathrm{g} \cdot \mathrm{mL}^{-1}$ is of no clinical relevance, the other two concentrations used ( 1 and $10 \mu \mathrm{g} \cdot \mathrm{mL}^{-1}$ ) are within the same range as those achieved in patients 0.5-15 min after administration of a single bolus thiopentone $i v$ dose for induction of anesthesia. ${ }^{17}$ Furthermore, both in vitro studies investigating the effects of thiobarbiturates on $\mathrm{K}_{\text {ATP }}$ channels in isolated cells ${ }^{9,10}$ reported a blocking effect at concentrations that are within the range of both lower concentrations used in the present study.

We investigated direct effects of thiopentone on the myocardium by using the model of isolated buffer perfused rat hearts. This model excludes systemic effects of thiopentone that may be important in the in vivo situation of myocardial ischemia and reperfusion (hemodynamic and humoral side effects, sympathetic nervous system activity) and changes in collateral blood flow influencing ischemic injury. Therefore, effects of thiopentone on ischemic preconditioning in vivo can be different from in vitro results.

Ischemic preconditioning is still a laboratory-based phenomenon that has not been conclusively documented in patients. However, some in vitro evidence of ischemic preconditioning in humans exists ${ }^{12}$ and there are several possible clinical scenarios in which ischemic preconditioning might occur, e.g., unstable angina preceding myocardial infarction ${ }^{2}$ and percutaneous transluminal coronary angioplasty. ${ }^{18}$ It may therefore be of interest to avoid the use of anesthetic agents that block this strong endogenous cardioprotective mechanism against myocardial ischemia. In contrast to the detrimental effects of $\mathrm{K}_{\mathrm{ATP}}$ channel blockade, $\mathrm{K}_{\mathrm{ATP}}$ agonists, including anesthetics like isoflurane ${ }^{8,19}$ or opioids, ${ }^{20}$ are suggested to provide organ protection intraoperatively during cardiac, vas- cular or neurosurgery. On the other hand, iv anesthetics like ketamine can block the cardioprotective effects of ischemic preconditioning. ${ }^{6,7}$ Our experimental findings now clearly suggest, that in contrast to recent findings with ketamine, ${ }^{6,7}$ thiopentone may be "safe" with regard to the maintenance of cardioprotection by ischemic preconditioning.

\section{References}

1 Baxter GF. Ischaemic preconditioning of myocardium. Ann Med 1997; 29: 345-52.

2 Kloner RA, Shook T, Antman EM, et al. Prospective temporal analysis of the onset of preinfarction angina versus outcome. An ancillary study in TIMI-9B. Circulation 1998; 97: 1042-5.

3 Lin $\Upsilon$, Sato T, O'Rourke B, Marban E. Mitochondrial ATP-dependent potassium channels. Novel effectors of cardioprotection. Circulation 1998; 97: 2463-9.

4 Ko S-H, Lee S-K, Han $\Upsilon$-J, et al. Blockade of myocardial ATP-sensitive potassium channels by ketamine. Anesthesiology 1997; 87: 68-74.

5 Cason BA, Shubayev I, Hickey RF. Blockade of adenosine triphosphate-sensitive potassium channels eliminates isoflurane-induced coronary artery vasodilation. Anesthesiology 1994; 81: 1245-55.

6 Molojavyi A, Preckel B, Comfêre T, Müllenheim J, Thämer V, Schlack W. Effects of ketamine and its isomers on ischemic preconditioning in the isolated rat heart. Anesthesiology 2001; 94: 623-9.

7 Müllenheim J, Fräßdorf J, Preckel B, Thämer V, Schlack $W$. Ketamine, but not $S(+)$-ketamine blocks ischemic preconditioning in rabbit hearts in vivo. Anesthesiology 2001; 94: 630-6.

8 Ismaeil MS, Tkachenko I, Gamperl AK, Hickey RF, Cason BA. Mechanisms of isoflurane-induced myocardial preconditioning in rabbits. Anesthesiology 1999; 90: 812-21.

9 Kozlowski RZ, Ashford MLJ. Barbiturates inhibit ATP $\mathrm{K}^{+}$channels and voltage-activated currents in CRI- GI insulin-secreting cells. Br J Pharmacol 1991; 103: 2021-9.

10 Tsutsumi $\Upsilon$, Oshita S, Kitahata H, Kuroda $\Upsilon$, Kawano T, Nakaya $\Upsilon$. Blockade of adenosine triphosphate- sensitive potassium channels by thiamylal in rat ventricular myocytes. Anesthesiology 2000; 92: 1154-9.

11 Preckel B, Thämer $V$, Schlack $W$. Beneficial effects of sevoflurane and desflurane against myocardial reperfusion injury after cardioplegic arrest. Can J Anesth 1999; 46: 1076-81

12 Arstall MA, Zhao Y-Z, Hornberger L, et al. Human ventricular myocytes in vitro exhibit both early and delayed preconditioning responses to simulated ischemia. J Mol Cell Cardiol 1998; 30: 1019-25. 
13 Yao Z, Mizumura T, Mei DA, Gross GJ. $\mathrm{K}_{\mathrm{ATP}}$ channels and memory of ischemic preconditioning in dogs: synergism between adenosine and $\mathrm{K}_{\mathrm{ATP}}$ channels. Am J Physiol 1997; 272: H334-42.

14 Gross GJ, Fryer RM. Sarcolemmal versus mitochondrial ATP-sensitive $\mathrm{K}^{+}$channels and myocardial preconditioning. Circ Res 1999; 84: 973-9.

15 Inagaki N, Gonoi T, Clement IV JP, et al. A family of sulfonylurea receptors determines the pharmacological properties of ATP-sensitive $\mathrm{K}^{+}$channels. Neuron 1996 16: 1011-7.

16 Murry CE, Jennings RB, Reimer KA. Preconditioning with ischemia: a delay of lethal cell injury in ischemic myocardium. Circulation 1986; 74: 1124-36.

17 Burch PG, Stanski DR. The role of metabolism and protein binding in thiopental anesthesia. Anesthesiology 1983; 58: 146-52.

18 Deutsch E, Berger M, Kussmaul WG, Hirshfeld JW Jr, Herrmann HC, Laskey WK. Adaptation to ischemia during percutaneous transluminal coronary angioplasty. Circulation 1990; 82: 2044-51.

19 Roscoe AK, Christensen JD, Lynch III C. Isoflurane, but not halothane, induces protection of human myocardium via adenosine $A_{1}$ receptors and adenosine triphosphate-sensitive potassium channels. Anesthesiology 2000; 92: 1692-1701.

20 Schultz JEJ, Hsu AK, Nagase H, Gross GJ. TAN-67, a $\mathrm{d}_{1}$-opioid receptor agonist, reduces infarct size via activation of $\mathrm{G}_{\mathrm{i} / \mathrm{o}}$ proteins and $\mathrm{K}_{\mathrm{ATP}}$ channels. Am J Physiol 1998; 274: H909-14 